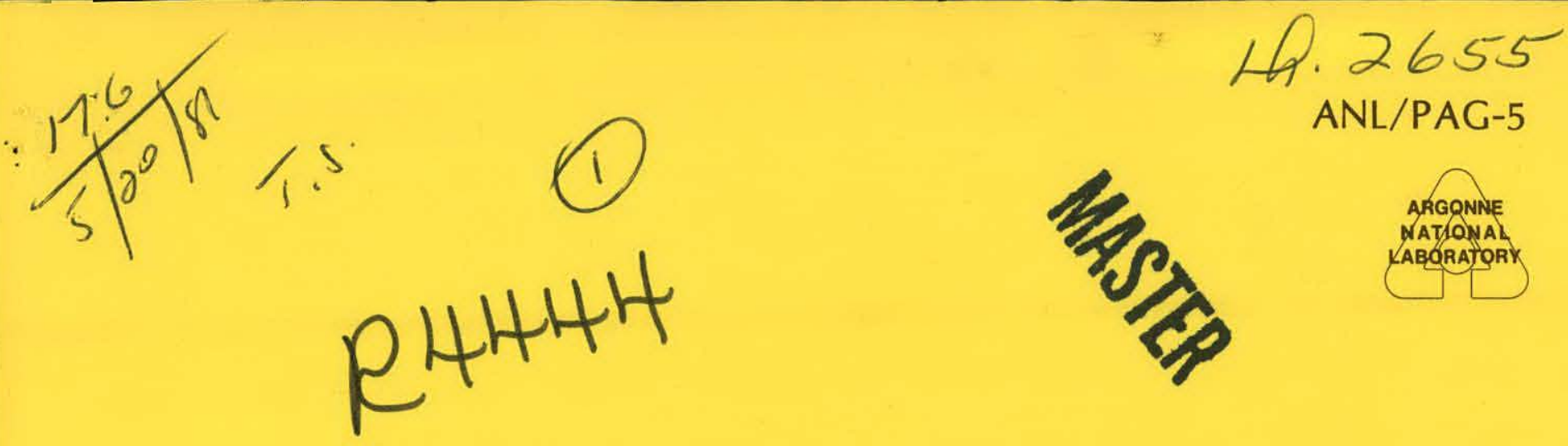

\title{
Organic Constituents in Process Water from the In-Situ Retorting of Oil from Oil-Shale Kerogen
}

\author{
Occidental Oil Shale, Inc., Logan Wash No. 6 \\ Retort Experiment
}

L. A. Raphaelian and W. Harrison

\section{ARGONNE NATIONAL LABORATORY}




\section{DISCLAIMER}

This report was prepared as an account of work sponsored by an agency of the United States Government. Neither the United States Government nor any agency Thereof, nor any of their employees, makes any warranty, express or implied, or assumes any legal liability or responsibility for the accuracy, completeness, or usefulness of any information, apparatus, product, or process disclosed, or represents that its use would not infringe privately owned rights. Reference herein to any specific commercial product, process, or service by trade name, trademark, manufacturer, or otherwise does not necessarily constitute or imply its endorsement, recommendation, or favoring by the United States Government or any agency thereof. The views and opinions of authors expressed herein do not necessarily state or reflect those of the United States Government or any agency thereof. 


\section{DISCLAIMER}

Portions of this document may be illegible in electronic image products. Images are produced from the best available original document. 
The facilities of Argonne National Laboratory are owned by the United States Government. Under the terms of a contract (W-31-109-Eng-38) among the U. S. Department of Energy, Argonne Universities Association and The University of Chicago, the University employs the staff and operates the Laboratory in accordance with policies and programs formulated, approved and reviewed by the Association.

\section{MEMBERS OF ARGONNE UNIVERSITIES ASSOCIATION}

The University of Arizona

Carnegie-Mellon University

Case Western Reserve University

The University of Chicago

University of Cincinnati

Illinois Institute of Technology

University of Illinois

Indiana University

The University of Iowa

Iowa State University
The University of Kansas

Kansas State University

Loyola University of Chicago

Marquette University

The University of Michigan

Michigan State University

University of Minnesota

University of Missouri

Northwestern University

University of Notre Dame
The Ohio State University

Ohio University

The Pennsylvania State University

Purdue University

Saint Louis University

Southern Illinois University

The University of Texas at Austin

Washington University

Wayne State University

The University of Wisconsin-Madison

\section{-NOTICE}

This report was prepared as an account of work sponsored by an agency of the United States Government. Neither the United States Government or any agency thereof, nor any of their employees, make any warranty, express or implied, or assume any legal liability or responsibility for the accuracy, completeness, or usefulness of any information, apparatus, product, or process disclosed, or represent that its use would not infringe privately owned rights. Reference herein to any specific commercial product, process, or service by trade name, mark, manufacturer, or otherwise, does not necessarily constitute or imply its endorsement, recommendation, or favoring by the United States Government or any agency thereof. The views and opinions of authors expressed herein do not necessarily state or reflect those of the United States Government or any agency thereof.

Printed in the United States of America

Available from

National Technical Information Service

U. S. Department of Commerce

5285 Port Royal Road

Springfield, VA 22161

NTIS price codes

Printed copy: A03

Microfiche copy: A01 
ARGONNE NATIONAL LABORATORY

9700. South Cass Avenue

Argonne, Illinois 60439

ORGANIC CONSTITUENTS IN PROCESS WATER

FROM THE IN-SITU RETORTING OF OIL FROM OIL-SHALE KEROGEN

Occidental Oil Shale, Inc., Logan Wash No. 6

Retort Experiment

by

L. A: Raphaelian and W. Harrison

Energy and Environmental Systems Division

February 1981 This book was prepared as an account of work sponsored by an agencer of the their employecs. moles any Neither the Unized States Golied of assumes any legal liability or responstb process disclosed. or

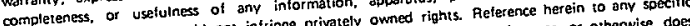
complesents that is use would not infringe privately owmed righs. Anafoctures, or otherwise, does commercial product, process. of service by trade namie. wademmendation. or favoring by the United not necessarily constitute or imply its endorsement, The opinions of authors expressed

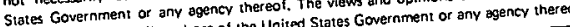

work sponsored by

U.S. DEPARTMENT OF ENERGY

Assistant Secretary for Environment

Office of Environmental Compliance and Overview 
CONTENTS

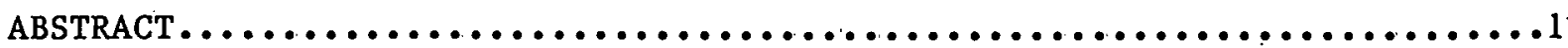

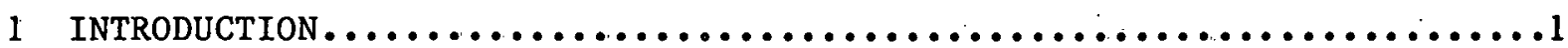

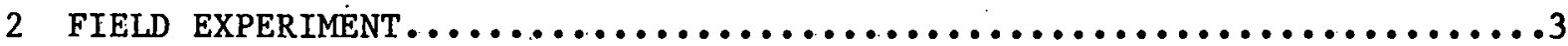

3 SAMPLE HISTORY AND SAMPLE WORKUP $\ldots \ldots \ldots \ldots \ldots \ldots \ldots \ldots \ldots \ldots \ldots \ldots \ldots \ldots \ldots \ldots \ldots$

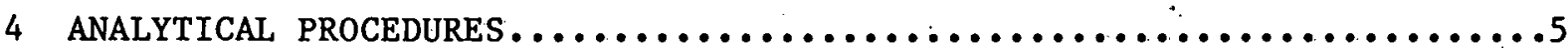

4.1 Type of Equipment and Operating

Conditions Employed...................................

4.2 Methods Used for Identification

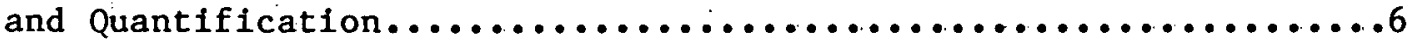

5 RESULTS...........................................

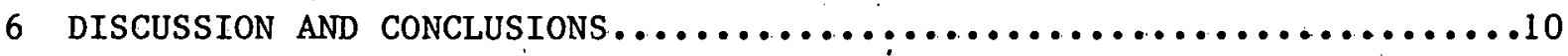

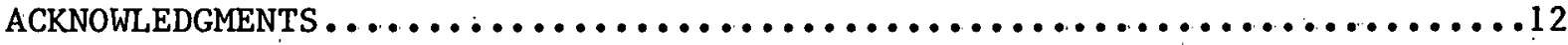

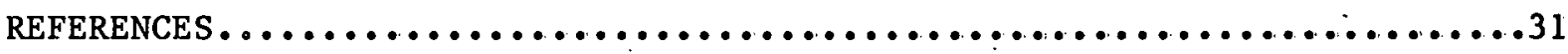

FIGURES

3.1 Schematic of 0xy Retort 6 Experiment Showing

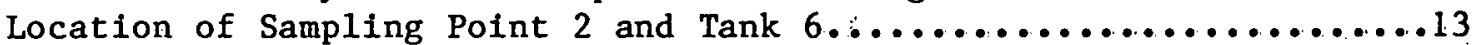

5.1 Capillary Column GC Chromatograms of Neutra1-

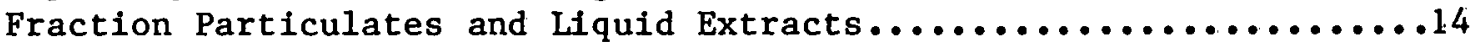

5.2 Capillary Column GC Chromatograms of Base-

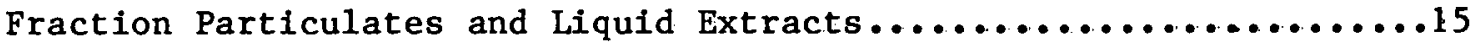

5.3 Capillary Column GC Chromatograms of Acid-

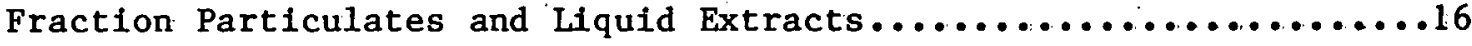

TABLES

4.1 Determination of FID/GC Sensitivity of Some Representative Neutral Organic Compounds....................17

4.2 Determination of FID/GC Sensitivity of Some Representative Basic Organic Compounds.....................18

4.3 Determination of Reproducibility and of FID/GC Sensitivity of Some Representative

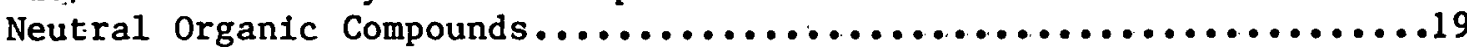




\section{TABLES (Contd.)}

4.4 Determination of Reproducibility, FID/GC

Sensitivity, and Split Ratio of Some Representative

Basic Organic Compounds..............................20

4.5 Average Area Counts Determined from Tables

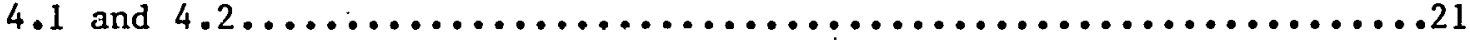

5.1 Compounds in the Neutral Fraction of the

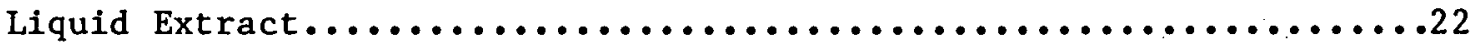

5.2 Compounds in the Neutral Fraction of the

Particulates Extract.................................23

5.3 Compounds in the Base Fraction of the

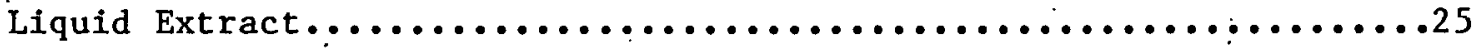

5.4 Compounds in the Base Fractions

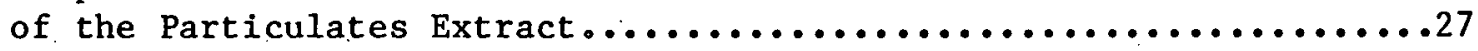

5.5 Compounds in the Acid Fraction of the

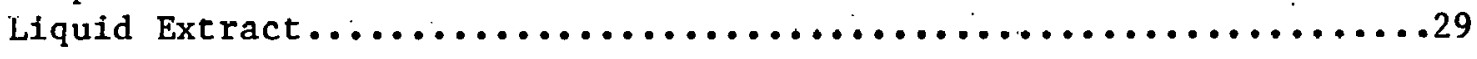

5.6 Compounds in the Acid Fraction of the Particulates Extract. 


\begin{abstract}
ORGANIC CONSTITUENTS IN PROCESS WATER
FROM THE IN-SITU RETORTING OF OIL FROM OIL-SHALE KEROGEN

Occidental Oil Shale, Inc., Logan Wash No. 6

Retort Experiment
\end{abstract}

by

L. A. Raphaelian and W. Harrison

\begin{abstract}
Capillary-column gas-chromatography/mass-spectrometry on the acid, base, and neittra (iquid- and particulate-phase methylene chloride extracts of a composite sample of raw process water collected from separator Tank 6 by the Laramie Energy Technology Center. Of the 160 extractable and chromatographable organic compounds tentatively identified, the following compound classes were found (listed in decreasing order of abundance): quinolines and lower fatty acids, aminoindoles, neutral oxygenated heterocyclics, pyridines, pyrroles, pyrazoles, phenols, and alkanes. Noticeably absent or in low concentration were alkyl benzenes and alkenes. Assuming $100 \%$ extraction efficiency, these organics constitute approximately $0.035 \%$ of the retort water; approximately $50 \%$ of this amount is represented by the quinolines, fatty acids, aminoindoles, and oxygenated heterocyclics. The following differences were noted in the composition of the particulate and liquid extracts of the neutral and base fractions, respectively: (1) alkanes are a major portion of the particulates, whereas oxygenated heterocyclics are most prominent in the liquid; and (2) aminoindoles are only a minor portion of the particulates, but are prominent in the liquid phase. The concentration of a compound occurring in both the 1iquid and particulate extracts is approximately 40100 times higher in the liquid than in the particulate extract.
\end{abstract}

\title{
1 INTRODUCTION
}

One of the leading oil-shale extractive technologies under consideration for commercialization involves the underground retorting of oil shales found in the Green River formation of the western United States. Occidental Oil Shale, Inc., a subsidiary of Occidental Petroleum (Oxy), has demonstrated a modified in-situ (MIS) retorting process., The process involves digging a tunnel to the bottom of an oil-shale bed and then excavating shale to create a room of the same cross section as the future retort. Holes are 
then drilled through the roof of the room to the desired height of the retort. Explosives are, inserted and detonated, creating a column-shaped underground retort filled with shale rubble.

After sealing the access tunnel, air and burning fuel gas are injected into the top of the rubble pile through a specially constructed injection hole. Heat from the combustion of the top layers moves downward in the gas. stream and oil vapors are carried down the retort to a sump at the bottom, from which they are removed to the surface by pumping. The combustion zone moves slowly. down the retort, fueled by residual carbon in the retorted layers. Combustion ceases when the burn zone reaches the bottom of the retort and the flow of air is stopped. Formation and combustion-process water is released during a burn and this "process "water," contaminated with organic combustion products, is the type characterized in the present study.

Previous work on chemical characterization of oil-shale waters has been directed primarily toward inorganic species and water quality parameters. Fox, Farrier, and Poulson (1978) have summarized the earlier studies and presented new information on Omega-9 water"from the in-situ combustion experiment, at the Laramie Energy Technology Center's (LETC's) site at Rock Springs, Wyoming. Pellizzari et al. (1979) did a GC/MS study of organics in the same Omega-9 in-situ retort water. They identified 97 compounds, compared to the 160 compounds identified in the present study. 


\section{FIELD EXPERIMENT}

Oxy's work began in 1972 along Logan Wash, a private tract on the southern fringe of the Piceance basin," about $50 \mathrm{mi}$ northeast of Grand Junction, Colorado. Oxy uses a vertical burn in its MIS process; that is; the combustion zone progresses vertically through the shale bed (Office of Technology Assessment, 1980, p. 132). The burning of Oxy's No. 6 retort began in 1978 . About $40 \%$ of the oll in place was recovered. 


\section{SAMPLE HISTORY AND SAMPLE WORKUP}

Water studied by Argonne represents oily water from retort No. 6 that was sampled at point 2 (Fig. 3.1)* on February 11, March 10, Apri1 22, and May 17, 1979. Sampling point 2 is known as "Tank 6." The following historical statement for Sample point 2, Tank 6 water, was provided by the Division of Environmental Sciences, Laramie Energy Technology Center (LETC).

Sample point $2 \ldots$ is located outside the mine on the lower mine bench. Tank 6 was not in operation from January-April 1979. The January-April samples were taken from a pipe downstream of the small separator tanks ( 1 and $1 B$ ) underground and were pumped by a Moyno pump into the drum with an existing hose at the sample location. The May sample was pumped from the TK 6 water compartment. A two-inch hose was run from an opening in the top of the tank to the drums in the refrigerated trailer. When the oily water was pumped to TK 6 , the small separator tanks were by-passed. Therefore the early samples, as well as the May sample, represent the first oilwater separation after the Retort $6^{\text {'bulkhead. There is no }}$ difference between the use of TK 1 and $1 \mathrm{~B}$ or TK 6 for oilwater separation. Sample point 2 was preceded by oil-water separation in the tank. In both cases the water was in the tanks 8-24 hours prior to pumping. This sample was loaded into a. refrigerated trailer within 24 hours, usually during the same shift. In the case of the TK 6 (May sample), it was immediately loaded into the refrigerated trailer.

The sample provided to Argonne by LETC consisted of 5 gal of a 3330-gal composite sample from the following four sampling efforts:

\begin{tabular}{lc} 
Sampling Date & Amount (gal) \\
\hline $2 / 11 / 79$ & 810 \\
$3 / 10 / 79$ & 840 \\
$4 / 11 / 79$ & 840 \\
$5 / 17 / 79$ & 840
\end{tabular}

LETC designated Argonne's sample as 79-0XY-6-02W-00C.

Upon arrival at Argonne, the sample was filtered and the water and particulates were each separated by a liquid-liquid extraction, with methylene chloride as the solvent, into acid, base, and neutral fractions for GC/MS analysis.

*Figures and tables appear consecutively at the end of the report. 


\section{ANALYTICAL PROCEDURES}

\subsection{TYPE, OF EQUIPMENT AND OPERATING CONDITIONS EMPLOYED}

This study used capillary-column GC/MS to identify the organic constituents extracted from the aqueous and particulate phases and capillarycolumn GC with flame ionization detection (FID) to quantify the amount. of each organic constituent. Quantification was based on a set of standard compounds that, were representative of those found in the sample extracts.

. The GC used in this study was the Hewlett-Packard (HP) 5840 fitted with a variety of accessories, including cryogenic cooling with liquid carbon dioxide, extra peak storage for integrated areas of up to 500 peaks, and the second generation HP capillary-column injection port (18835B), a modification of the Grob-type, splitless injection system. (The port could also be used to perform split injections.) An automatic sampler, the HP 7671, was used and the amount injected was set at either 1 or $3 \mu \mathrm{L}$. The capillary column used was the HP 50-meter fused-silica methyl silicone. (SP-2100) column with Carbowax 20M deactivation and a quoted maximum operating temperature of $280^{\circ} \mathrm{C}$. The oven was programmed during runs from 20 to $280^{\circ} \mathrm{C}$ at $2{ }^{\circ} \mathrm{C} / \mathrm{min}$ with a $2-\min$ hold at $20^{\circ} \mathrm{C}$ and a $20-\min$ hold at $280^{\circ} \mathrm{C}$. Injection port temperature was set at $225^{\circ} \mathrm{C}$ and FID temperature was set at 250 .

The GC/MS used in this study was the HP 5993A equipped with an HP 21MXE Computer with 32K, 16-bit-word, core memory, 7900A Dual Disc Drive with two $2.5 \mathrm{M}$ bytes discs. (one fixed and one removable), and a Tektronix 4012 Graphic Display Terminal. Peripheral equipment included a Tektronix 4631 Hard Copy Unit and a Zeta 130-10 Incremental Plotter. The capillary-column injection port delivered with the system was replaced with parts from an HP $18835 \mathrm{~B}$ Capillary Inlet System. A digital electronic timer was used for turning on or off the valves used to purge solvent in Grob-type splitless injection and to by-pass the solvent peak to avold overload of the mass spectrometer's pumping system.

Operating conditions for the GC portion of the GC/MS were the same as those used in the GC-only runs (see above). That is, the oven was programmed from $20-280^{\circ} \mathrm{C}$ at $2^{\circ} \mathrm{C} / \mathrm{min}$ with a $2-\min$ hold at $20^{\circ} \mathrm{C}$ and a $18-\mathrm{min}$ hold at $280^{\circ} \mathrm{C}$. The injection port was set at $225^{\circ} \mathrm{C}$ and the column was an $\mathrm{HP} 50-\mathrm{m}$, fused-silica methyl silicone (SP-2100) with Carbowax 20M deactivation. 
Collection and analysis of data was done with the SIMAQ and SPEED programs, giving foreground collection of data and background analysis of data. The mass range scanned was 50-400 AMUs and, depending upon the A/D measurements made per datum point (each 0.1 AMU), the cycle time was either approximately $2 \mathrm{sec}$ (for $1 \mathrm{~A} / \mathrm{D}$ ) or $4 \mathrm{sec}$ (for $2 \mathrm{~A} / \mathrm{Ds}$ ). Other parameters were threshold at 20 and electron multiplier at 2200 or $2400 \mathrm{~V}$, depending upon the concentration of the sample:

Standards used in determining response factors and reproducibility of the HP 5840 GC were obtained from. Aldrich Chemical Company, Milwaukee, Wisconsin; Eastman Kodak Company, Rochester, New York; or Fischer Scientific Company, Fair Lawn, New Jersey.

\subsection{METHODS USED FOR IDENTIFICATION AND QUANTIFICATION}

Each of the fractions was run, as is, on the GC using a split ratio of approximately 20 and an injection volume of $1 \mu \mathrm{L}$. An inspection of each GC chromatogram was then made to guide the subsequent analysis as follows:

1. If it was satisfactory, the fraction was used without dilution or concentration for quantitation of peaks,

2. If it showed "overload," the fraction required dilution (an estimate of the dilution required was made and the fraction was rerun at that dilution),

3. If it was slightly "weak," indicating that an additional small amount of the fraction was required to produce a satisfactory chromatogram, the fraction was then rerun with $3-\mu \mathrm{L}$. injection and a split-ratio of approximately 20 ,

4. If it was very weak, indicating that considerably more of the fraction would be required to produce an acceptable run, the GC injector was modified to a Grob-type splitless injector and a $1-\mu \mathrm{L}$ sample was run,

5. If the chromatogram from the 1- $\mu \mathrm{L}$ splitless injection was found to be slightly weak, the fraction was run at $3-\mu \mathrm{L}$ splitless; if found to be very weak, the fraction was concentrated and run at $3-\mu \mathrm{L}$ splitless.

Once the concentration and method of injection had been established, capillary-column GC/MS was run to identify the peaks in the GC chromatograms. That is, the capillary-column GC/MS was used for identification and the GC for quantification of the identified peaks (and for establishing the quantity, dilution or concentration of sample, and 
injection method, split or splitless, required for both quantification by GC and identification of peaks by GC/MS).

Organic compounds were identified by inspection of the fragmentation patterns, of the mass spectra and the associated retention time and/or by comparison with spectra or data in the ASTM. Index of Mass Spectral Data (1969), or Stenhagen, Abrahamson, and McLaffety's Registry of Mass Spectral Data (1974), or Heller and Milne's EPA/NIH Mass Spectral Data Base (1978).

The organic compounds identified were quantified using the integrated areas (area counts) of the HP $5840 \mathrm{GC}$ and the response factors of representative compounds developed in standard runs with split and splitless injection, and with 1 - and 3- $\mu \mathrm{L}$ injection (Tables 4.1-4.4).* As can be seen from Tables 4.3 and 4.4 , the split ratio lies between 18 and 22 for most compounds; the ratio of area counts for a $3-\mu \mathrm{L}$ to a $1-\mu \mathrm{L}$ injection appears to. be approximately 3. Thus, for calculating the concentration of compounds in these samples, a split ratio of 20 was used, and it was assumed that a $3-\mu \mathrm{L}$ sample was three times as large as a 1- $\mu \mathrm{L}$ sample. For determining concentration, average and estimated values for area counts per nanogram for

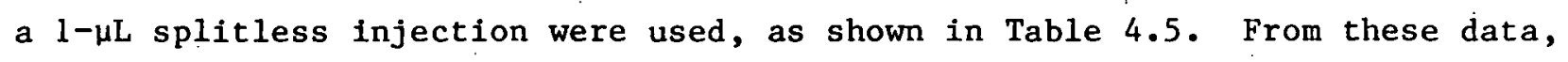
corresponding data can be developed for a 3- $\mu \mathrm{L}$ splitless injection (three times the number of area counts), a $1-\mu \mathrm{L}(20: 1)$ injection (one-twentieth the number of area counts), and a 3- $\mu \mathrm{L}(20: 1)$ injection (three-twentieths of the number of area counts).

*Tables and figures appear consecutively at the end of the report. 


\section{RESULTS}

GC chromatograms for the liquid and particulate phases of the neutral fraction are shown in Fig. 5.1, for the base fraction in Fig. 5.2, and for the acid fraction in Fig. 5.3. Tentative compound identifications and concentration in $\mu \mathrm{g} / \mathrm{L}$ of compounds in the neutral, base, and acid fractions (for both liquid and particulates) are given in Tables 5.1-5.6. These compound concentration data represent the methylene-chloride extractable and GC-chromatographable compounds. (Some polar compounds, such as the lower fatty acids; would be expected to be poorly extractable.)

Although the GC chromatogram traces (Figs. 5.1-5.3) have been normalized for comparison, it can be readily seen from the tables that the concentration of any compound occurring in both the liquid and particulate fractions is approximately 10-400 times higher in the liquid than in the particulate extract. This increased concentration is not unexpected because the surface area of the particulates is small and continual solvation or partitioning is taking place between the particulates and the liquid.

In the neutral fraction, with the exception of the n-alkanes and other alkanes, which are nicely detalled (Fig. 5.1) in the particulates extract, a number of unresolved peaks in the liquid phase generally could not be identified by GC/MS due to high background (or poor resolution due to the complexity of the mixture). Where identification was possible, there were some alkylated furans, thiazoles, and cyclohexanes. Also, it is apparent that the particulates extract contains more alkanes (relative to other neutral compounds) than does the liquid. Surprisingly, alkenes and alkyl benzenes were found in only small amounts.

In the base fraction, as shown in Fig. 5.2, the GC chromatograms of both the particulate and liquid extracts are remarkably similar except that the liquid extract. contains some compounds that have been tentatively identified as aminoindoles. The predominant compounds are quinolines (and the aminoindoles) with smaller amounts of pyridines, pyrroles, and pyrazoles. Saturated compounds such as piperidines or pyrrolidines were noticeably lacking.

In the acid fraction (FIg. 5.3), considerable similarity exists between the particulates and liquid fractions. The particulate extract contains fatty 
acids from acetic $\left(C_{2}\right)$ through pelargonic $\left(C_{9}\right)$, and the liquid, from $C_{3}$ (propionic) through $C_{10},($ capric). Small amounts of phenols are also present in the extracts.

Generally; the predominant extractable and chromatographable organic constituents in the 0xy 6 process wastewater are the non-neutral compounds, quinolines and lower fatty acids and, to a lesser extent, pyridines, pyrroles, pyrazoles, and phenols. A class of basic compounds that appears to be aminoindoles is also present in relatively high concentration. In the neutral fraction, some neutral oxygenated heterocyclics appear to be present in moderate amounts and some alkanes, in small amounts. Overall, the samples are. abundant in heteroatoms, particularly nitrogen and oxygen, and tend toward. aromaticity and unsaturation with the exception that alkyl benzenes and alkenes are either not present or present in small quantities. 


\section{DISCUSSION AND CONCLUSIONS}

An examination of the differences in organic constituents in the liquid and particulate phases is in order. In the neutral fraction of the particulates extract, alkanes (particularly n-alkanes) along with phytane and pristane predominate; in the neutral fraction of the liquid extract, however, the n-alkanes are only a minor component. Although the particulates contain many of the compounds present in the liquid, there is a clear difference in compounds adsorbed onto or inherently part of the particulates. Moreover, because of the difficulty in resolving and identifying the major components of the liquid, and the discrimination of the alkanes, it would seem that these unidentified neutral compounds are the more polar neutral substances, such as furans, cyclohexanones, dioxanes, pyrans, etc. To identify these complex. mixtures, further fractionation (with, for example, HPLC) would be required to simplify them. Thus, both the particulates and the liquid phases of the neutral fraction contain the same compounds, but a difference exists in that the particulates phase contains mostly alkanes.

Both the liquid- and particulate-phase extracts of the base fractions contain essentially the same compounds. However, relative to the neutral fraction, the ratio of the concentration of any one compound in the liquid to that in the particulate phase is considerably greater and is generally of the order of 100 to 400. Differences in this ratio are apparent, however, within this group of compounds; for example, the pyrroles, whose pair of electrons make a sextet, thereby stabilizing the molecule and rendering it relatively nonpolar, have lower ratios than the pyridines. The predominant classes of compounds in this fraction seem to be the quinolines, their parents, the pyridines, and a third class, presently unidentified, that is possibly aminoindoles. It also appears that benzoquinolines may be present, although they were not found in this study.

Although the acid fractions of most fossil-fuel products typically contain a variety of akylated phenols, those of both the liquid- and particulate-phase extracts were remarkably similar and contain relatively small amounts of phenols and large quantities of carboxylic acids (up to $\mathrm{C}_{10}$ ): What was surprising was to find an abrupt drop-off after $\mathrm{C}_{8}$ (Fig. 5.3; Tables 5.5 and 5.6); only the lower acids were found. 
Overall, the Oxy 6 process water sample contains largely acid and base organic compounds and relatively small amounts of alkanes. The neutral fraction does contain some heteroatom compounds, such as furans, thiazoles, and related classes. Thiophenes, benzothiophenes, and other sulfur species normally present in petroleum oils appear to be lacking.

Future work on characterization of the organic constituents in this type of water should concentrate upon:

1. Fractionation of the neutral fraction by HPLC and further identificaton of the apparent oxygenated compounds by GC/MS,

2. Fractionation by HPLC and derivatization of the base fraction to aid in further identification of the apparent heterocyclic compounds present, and

3. Derivatization (to methyl esters) of the acid fraction for a more precise look at the fatty acids present, or direct injection of the retort water onto the GC column. 


\section{ACKNOWLEDGMENTS}

The 0xy 6 process-water sample was provided by the Division of Environmental Sciences, Laramie Energy Technology Center (LETC). The following individuals are thanked for critical review of the manuscript: L. Jackson (LETC) and E. Turner, Occidental Oil Shale, Inc. 


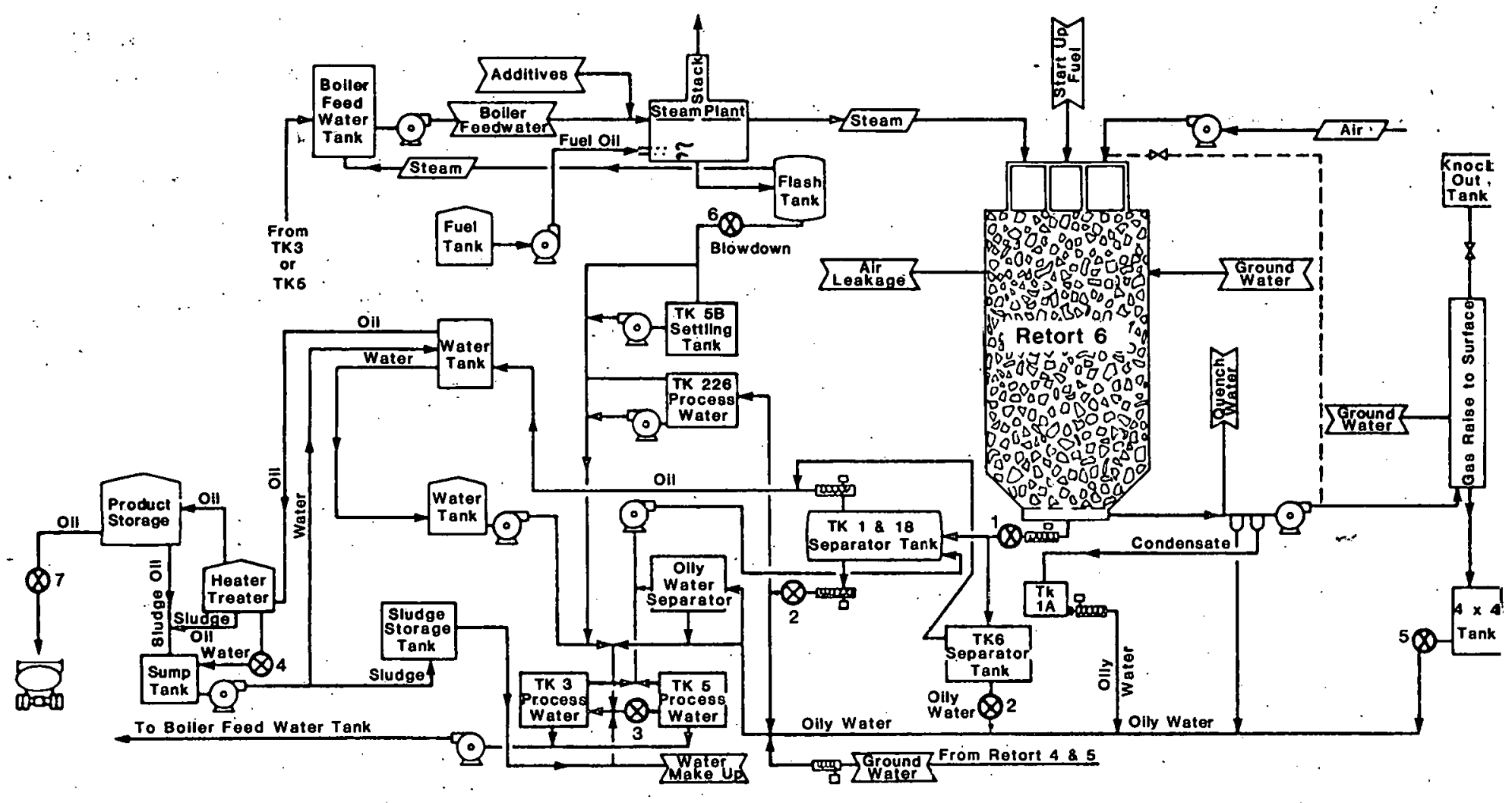

Fig. 3.1 Schematic of Oxy Retort 6 Experiment Showing Location of Sampling Point 2 and Tank 6 (TK6) 

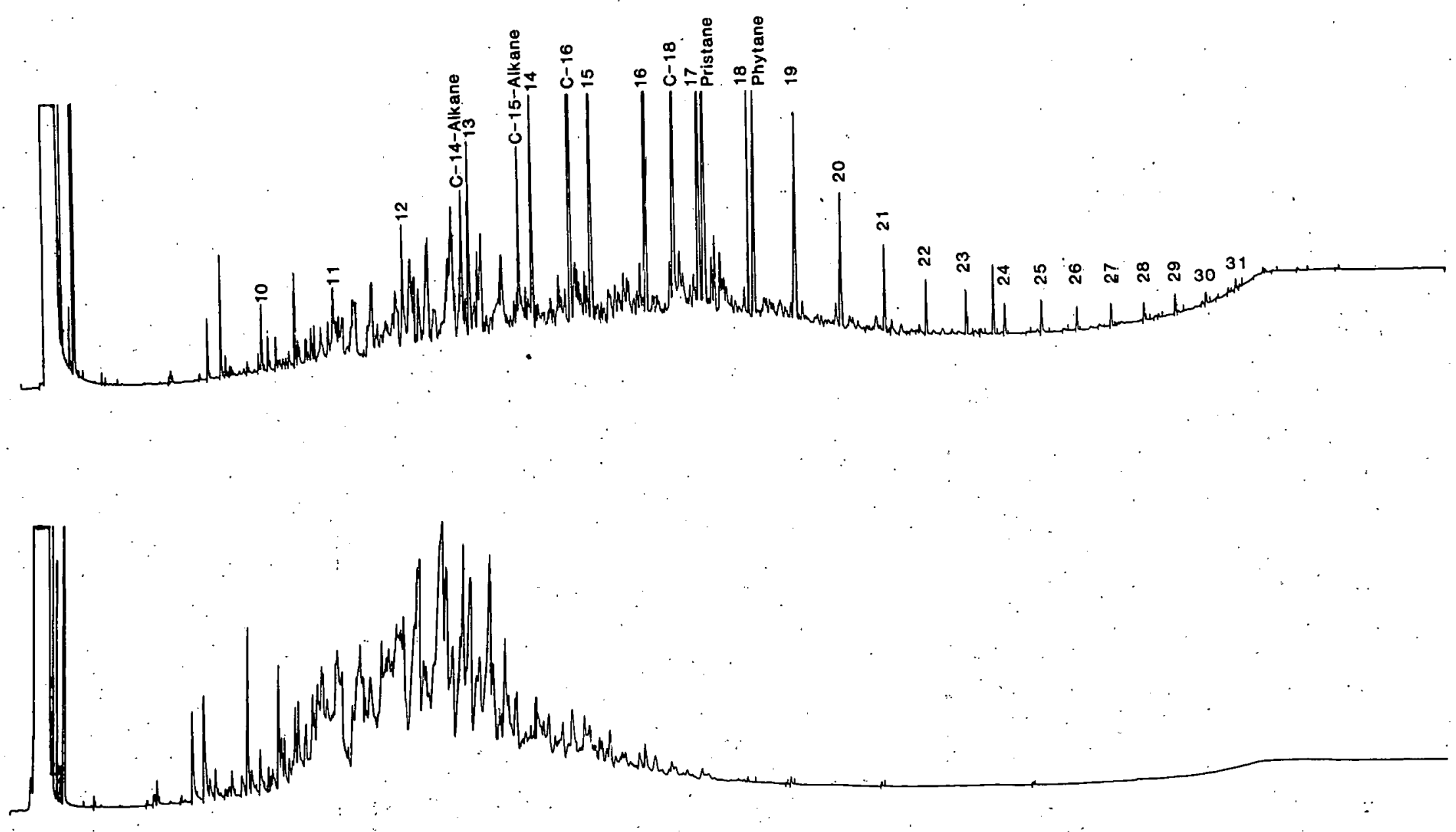

Fig. 5.1 Capillary Column GC Chromatograms of Neutral-Fraction Particulates (upper trace) and Liquid (lower trace) Extracts 

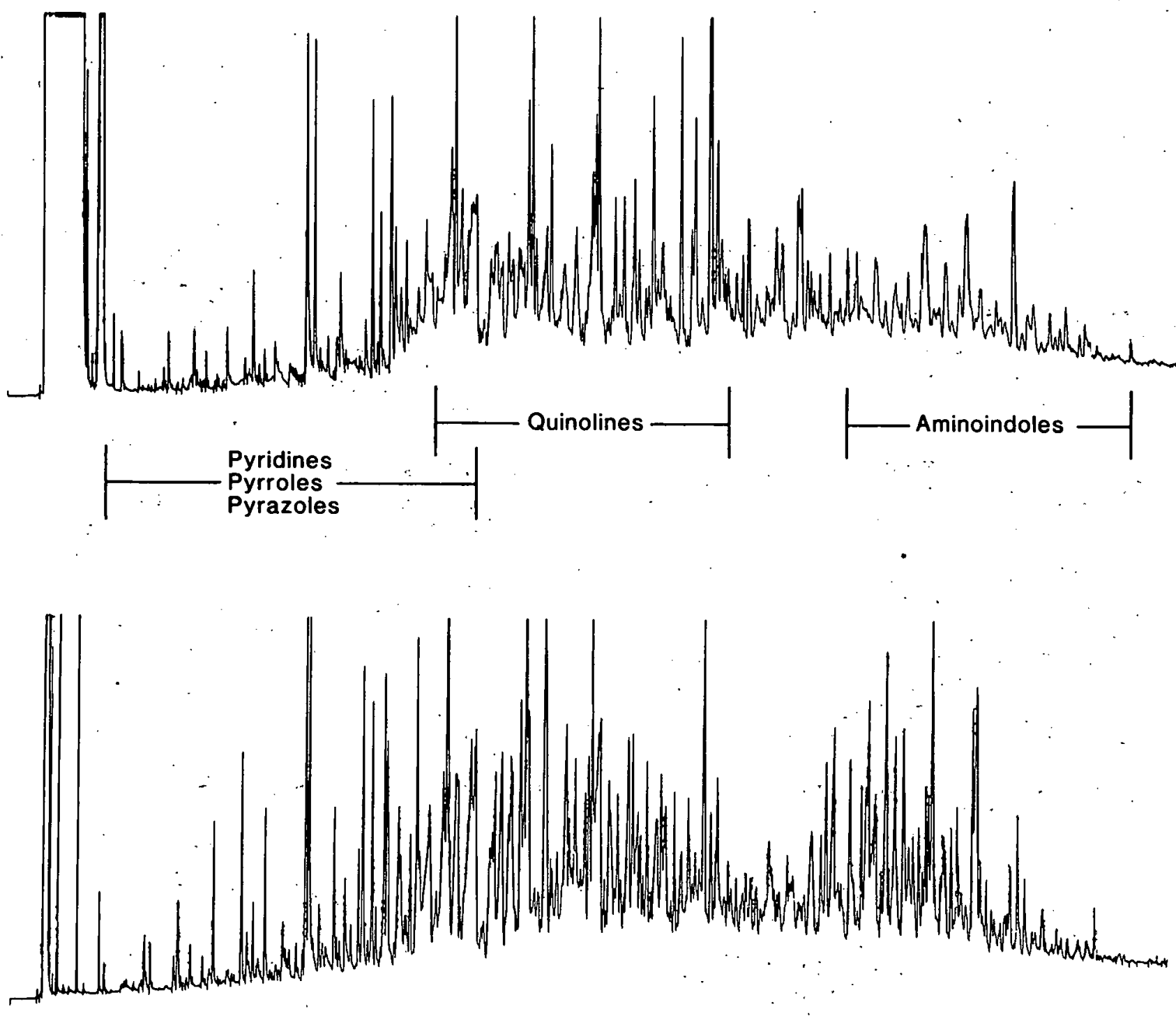

Fig. 5.2 Capillary Column GC Chromatograms of Base-Fraction Particulates (upper trace) and Liquid (lower trace) Extracts. 


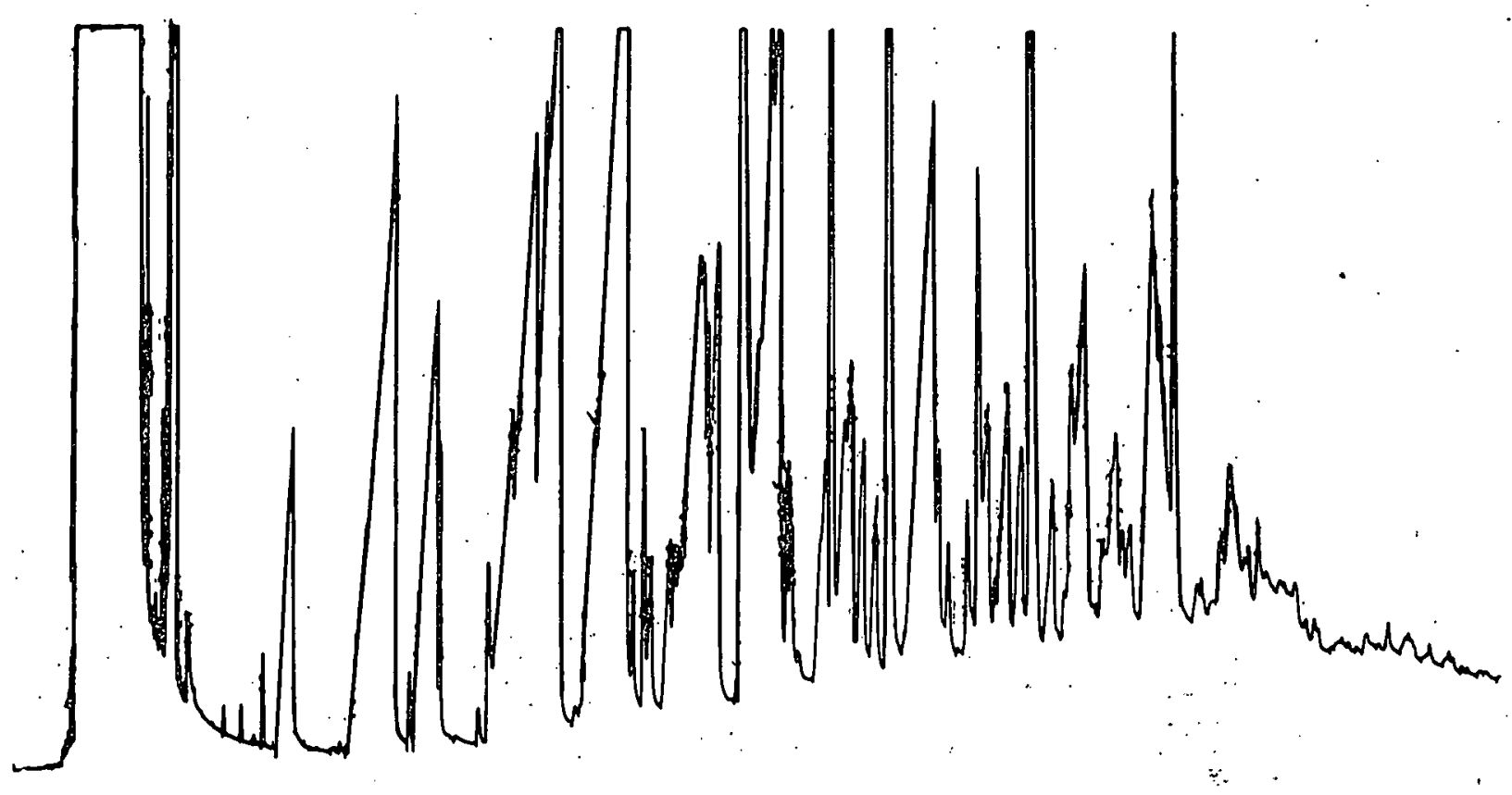

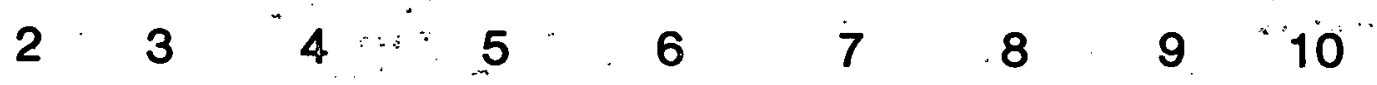

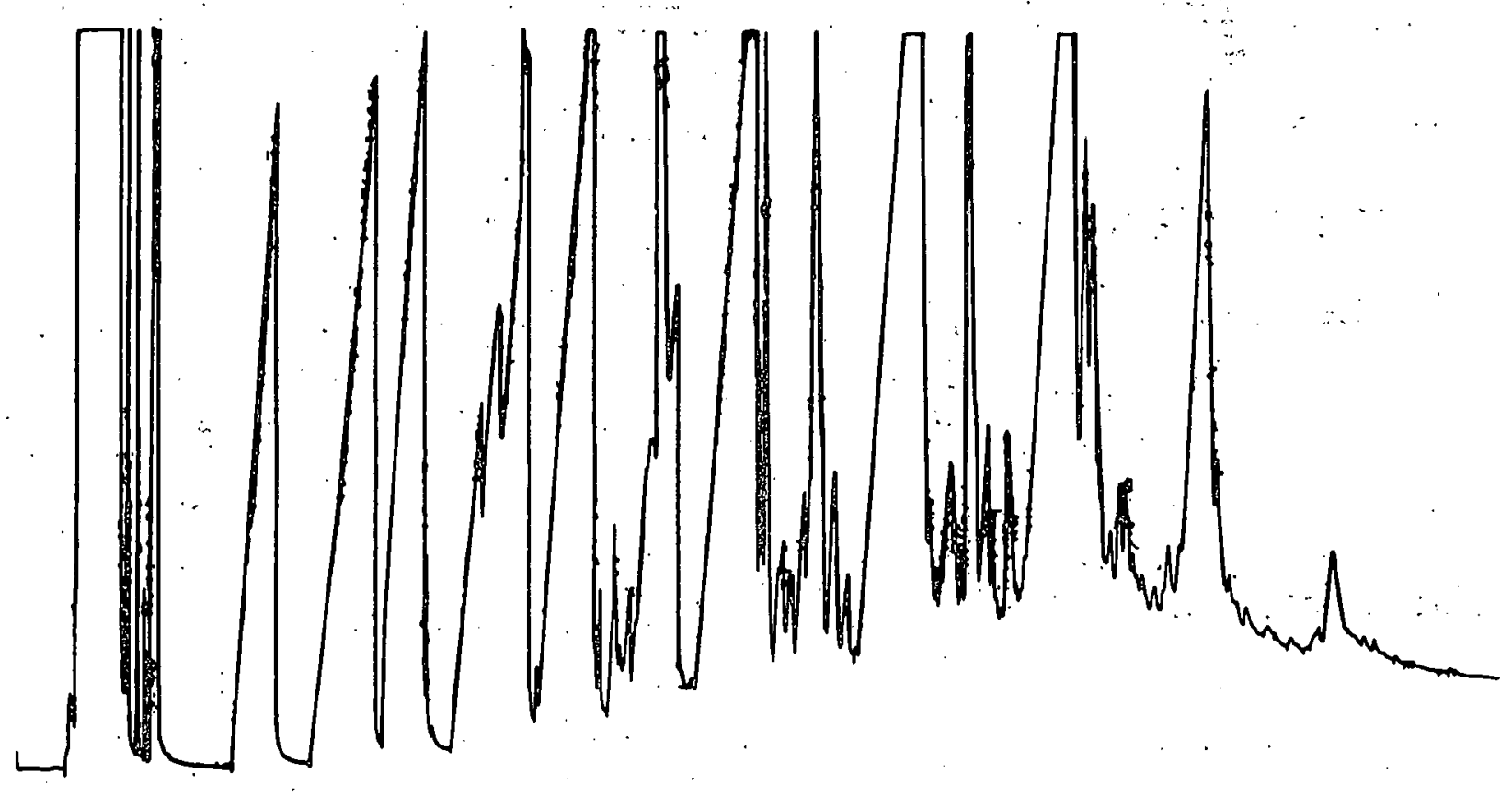

Fig. 5.3 Capillary Column GC Chromatograms of Acid-Fraction Particulates (upper trace) and Liquid (lower trace) Extracts 
Table 4.1 Determination of FID/GC Sensitivity of Some Representative Neutral Organic Compounds ( $1 \mu \mathrm{L}$ injection, splitless)

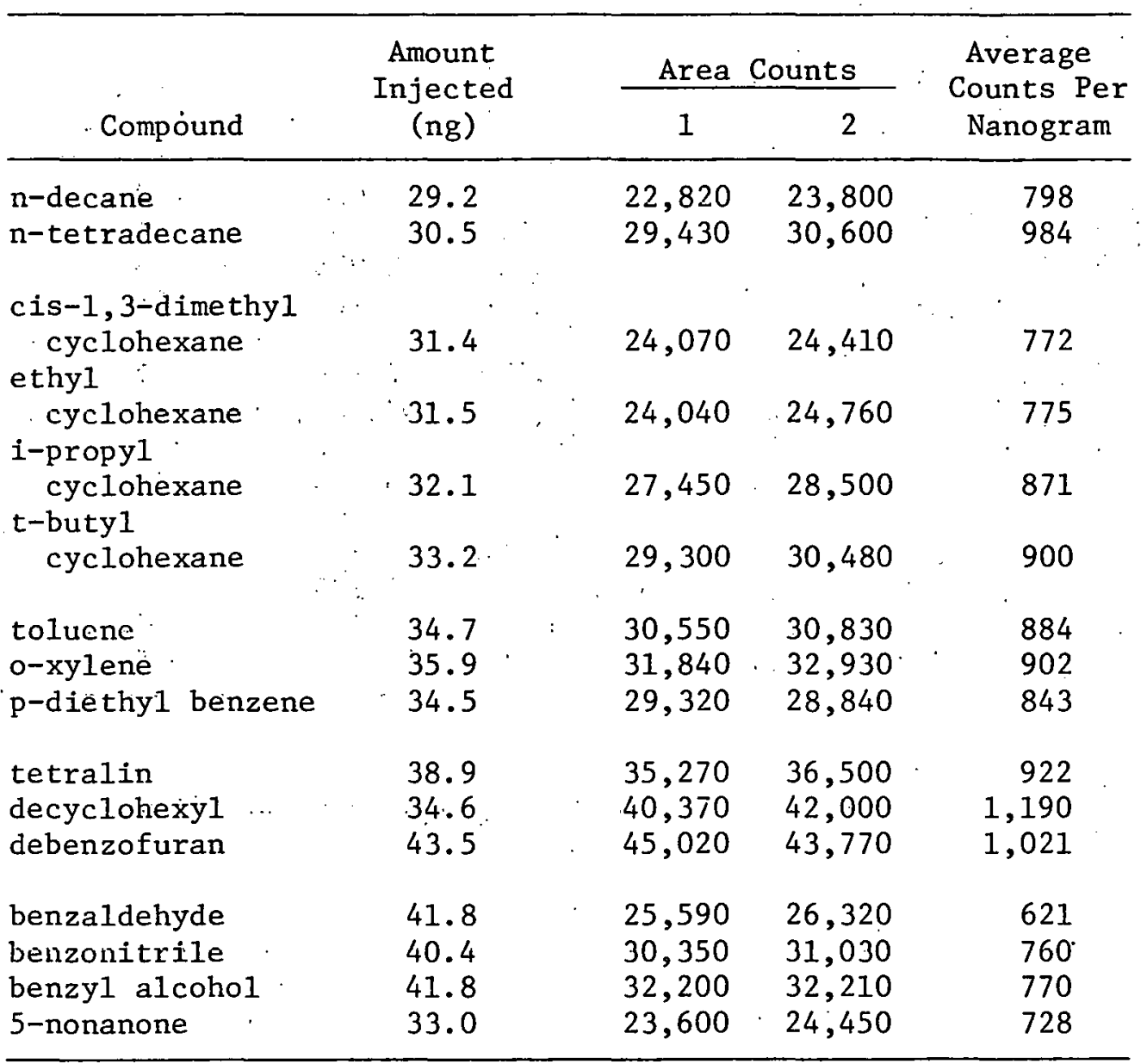


Table 4.2 Determination of FID/GC Sensitivity of Some Representative Basic Organic Compounds ( $1 \mu L$ injection, splitless)

\begin{tabular}{|c|c|c|c|c|}
\hline \multirow[b]{2}{*}{ Compound } & \multirow{2}{*}{$\begin{array}{l}\text { Amount } \\
\text { Injected } \\
\text { (ng) }\end{array}$} & \multicolumn{2}{|c|}{ Area Counts } & \multirow{2}{*}{$\begin{array}{c}\text { Average } \\
\text { (Counts/ng) }\end{array}$} \\
\hline & & 1 & 2 & \\
\hline pyridine & 39.1 & 17,710 & 17,670 & 452 \\
\hline 2-picoline & 37.7 & 17,320 & 16,930 & 454 \\
\hline 2,4-1utidine & 37.1 & 18,690 & 18,010 & 495 \\
\hline $2,4,6$-collidine & 36.7 & 19,480 & 19,160 & 526 \\
\hline aniline- $d_{5}$ & 40.9 & 8,936 & 7,966 & $207^{a}$ \\
\hline o-toluidine & 40.2 & 33,190 & 32,060 . & 812 \\
\hline 2,6-xylidine & 39.4 & 26,150 & 25,320 & 653 \\
\hline mesidine & 38.5 & 24,110 & 23,340 & 616 \\
\hline quinoline & $43.8^{\circ}$ & 29,490 & 28,730 & 664 \\
\hline indole & $\mathrm{NM}^{\mathrm{b}}$ & 293,100 & 285,900 & -- \\
\hline benzyl amine & 39.2 & 19,630 & 19,160 & 495 \\
\hline N-methyl aniline & 39.6 & 24,590 & 23,760 & 610 \\
\hline
\end{tabular}

Low due to deuteration.

$\mathrm{b}_{\text {Not measured; }}$ used for reproducibility and retention time studies. 
Table 4.3 Determination of Reproducibility and of FID/GC Sensitivity of Some Representative Neutral Organic Compounds $(3 \mu \mathrm{L}$ injection, split; split ratio approximately 22)

\begin{tabular}{|c|c|c|c|c|c|c|c|}
\hline \multirow[b]{2}{*}{ Compound } & \multirow{2}{*}{$\begin{array}{l}\text { Amount } \\
\text { Injected } \\
(\mathrm{ng} / \mu \mathrm{L})\end{array}$} & \multicolumn{4}{|c|}{ Area Counts } & \multirow{2}{*}{$\begin{array}{l}\text { Average - } \\
\text { Counts Per } \\
\text { Nanogram }\end{array}$} & \multirow{2}{*}{$\begin{array}{l}\text { Split } \\
\text { Ratio }\end{array}$} \\
\hline & & 1 & 2 & 3 & 4 & & \\
\hline $\begin{array}{l}\text { n-decane } \\
\text { n-tetradecane }\end{array}$ & $\begin{array}{l}29.2 \\
30.5\end{array}$ & $\begin{array}{l}3,007 \\
3,782\end{array}$ & $\begin{array}{l}3,449 \\
3,801\end{array}$ & $\begin{array}{l}2,910 \\
3,315\end{array}$ & $\begin{array}{l}3,227 \\
3,842\end{array}$ & $\begin{array}{l}35.9 \\
40.3\end{array}$ & $\begin{array}{l}22.2 \\
24.4\end{array}$ \\
\hline $\begin{array}{l}\text { cis-1,3-dimethyl } \\
\text { cyclohexane } \\
\text { ethyl }\end{array}$ & 31.4 & 3,499 & 4,027 & 3,398 & 3,779 & 39.0 & 19.8 \\
\hline $\begin{array}{l}\text { cyclohexane } \\
\text { i-propyl }\end{array}$ & 31.5 & 3,379 & 3,941 & 3,291 & 3,664 & 37.8 & 20.5 \\
\hline $\begin{array}{l}\text { cyclohexane } \\
\text { t-butyl }\end{array}$ & 32.1 & 3,718 & 4,308 & 3,642 & 4,056 & 40.8 & 21.3 \\
\hline cyclohexane & 33.2 & 3,951 & $\therefore 4,565$ & 3,851 & 4,297 & 41.8 & 21.5 \\
\hline $\begin{array}{l}\text { toluene } \\
\text { o-xylene } \\
\text { p-diethyl benzene }\end{array}$ & $\begin{array}{l}34.7 \\
35.9 \\
34.5\end{array}$ & $\begin{array}{l}4,333 \\
4,276 \\
4,717\end{array}$ & $\begin{array}{l}4,695 \\
4,909 \\
4,995\end{array}$ & $\begin{array}{l}3,868 \\
4,158 \\
4,067\end{array}$ & $\begin{array}{l}4,286 \\
4,567 \\
4,486\end{array}$ & $\begin{array}{l}41.3 \\
41.6 \\
44.1\end{array}$ & $\begin{array}{l}21.4 \\
21.7 \\
19.1\end{array}$ \\
\hline $\begin{array}{l}\text { tetralin } \\
\text { decyclohexyl }\end{array}$ & $\begin{array}{l}38.9 \\
34.6\end{array}$ & $\begin{array}{l}4,727 \\
5,718\end{array}$ & $\begin{array}{l}5,152 \\
5,890\end{array}$ & $\begin{array}{l}4,381 \\
5,005\end{array}$ & $\begin{array}{l}4,868 \\
--\end{array}$ & $\begin{array}{l}41.0 \\
53.3\end{array}$ & $\begin{array}{l}22.5 \\
22.3\end{array}$ \\
\hline $\begin{array}{l}\text { benzaldehyde } \\
\text { benzonitrile } \\
\text { 5-nonanone }\end{array}$ & $\begin{array}{l}41.8 \\
40.4 \\
33.0\end{array}$ & $\begin{array}{l}3,462 \\
4,072 \\
3,066\end{array}$ & $\begin{array}{l}3,814 \\
4,439 \\
3,368\end{array}$ & $\begin{array}{l}3,193 \\
3,789 \\
2,865\end{array}$ & $\begin{array}{l}3,521 \\
4,135 \\
3,206\end{array}$ & $\begin{array}{l}27.9 \\
33.9 \\
31.6\end{array}$ & $\begin{array}{l}22.2 \\
22.4 \\
23.1\end{array}$ \\
\hline
\end{tabular}

a Determined by dividing the average counts per nanogram for splitless injection by that for split injection. 
Table 4.4 Determination of Reproducibility, FID/GC Sensitivity, and Split Ratio. of Some Representative Basic Organic Compounds (1- and 3- $\mu \mathrm{L}$ injection, split)

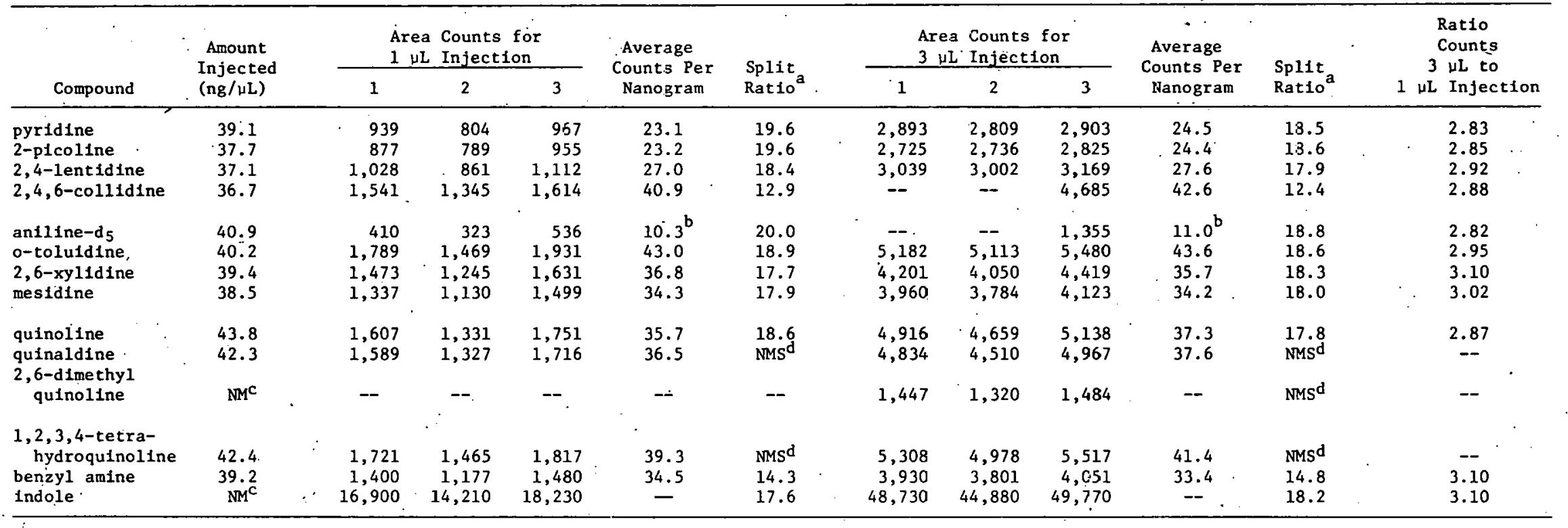

${ }^{a}$ Determined by dividing the average counts per nanogram for splitless injection by that for split injectich.

bow due to deuteration.

${ }^{c}$ Not measured.

dot measured splitless due to interferences. 
Table 4.5 Average Area Counts Determined from Tables 4.1 and 4.2

(1 $\mu \mathrm{L}$ injection, splitiless)

\begin{tabular}{lr}
\hline Type of Compound & $\begin{array}{c}\text { Area Counts } \\
\text { Per Nanogram }\end{array}$ \\
\hline Neutral Compounds & \\
alkanes & 830 \\
cyclohexanes & 830 \\
aromatic hydrocarbons & 880 \\
cyclic compounds & 1040 \\
polar compounds & 720 \\
Basic Compounds & \\
pyridines & 480 \\
anilines & 690 \\
miscellaneous & 590 \\
Miscellaneous Polar & \\
Compounds & \\
\hline
\end{tabular}


Table 5.1 Compounds in the Neutral Fraction of the Liquid Extract (1 $\mu \mathrm{L}$ splitless, 1:50 dilution)

\begin{tabular}{|c|c|c|c|c|c|}
\hline $\begin{array}{l}\text { Retention } \\
\text { Time, Min }\end{array}$ & Tentative & Identification & Area Counts ${ }^{a}$ & \multicolumn{2}{|c|}{$\begin{array}{c}\text { Concentration } \\
\mu \mathrm{g} / \mathrm{L}\end{array}$} \\
\hline 15.32 & $\mathrm{C}_{2}$-furan & & 498 & & 103 \\
\hline 19.02 & $\mathrm{C}_{2}$-furan & & 3,032 & & 627 \\
\hline 20.26 & methyl thiazole & & 4,583 & & 1,705 \\
\hline 20.85 & methyl thiazole & & 908 & & 338 \\
\hline $21.44^{\circ}$ & unidentified & & 841 & & - \\
\hline $23: 21$ & unidentified & & 743 & ' & - \\
\hline 24.79 & $\mathrm{n}$-decane & & 4,896 & & 1,023 \\
\hline 25.24 & unidentified & & 910 & & - \\
\hline 26.14 & $\mathrm{C}_{2}$-thiazole & : & 1,698 & & 632 \\
\hline 28.11 & $\mathrm{C}_{2}$-thiazole & & 4,840 & & 1,800 \\
\hline 28.46 & $\mathrm{C}_{2}$-thiazole & & 2,298 & & 855 \\
\hline 28.78 & $\mathrm{C}_{2}$-thiazole & & 2,200 & & 818 \\
\hline 29.91 & $\mathrm{C}_{3}$-thiazole & & 4,016 & & 1,494 \\
\hline 30.22 & $\mathrm{C}_{3}$-thiazole & . & 5,741 & & 2,136 \\
\hline 31.03 & $\mathrm{C}_{3}$-thiazole & & 4,093 & & 1,523 \\
\hline
\end{tabular}

area counts for $1: 50$ diluted sample. 
Table 5.2 Compounds in the Neutral Fraction of the Particulates Extract ( $1 \mu \mathrm{L}$ splitless)

\begin{tabular}{|c|c|c|c|c|}
\hline $\begin{array}{l}\text { Retention } \\
\text { Time, Min. }\end{array}$ & Tentative Identificat & tion & Area Counts & $\begin{array}{c}\text { Concentration } \\
\mu \mathrm{g} / \mathrm{L}\end{array}$ \\
\hline 15.71 & $\mathrm{C}_{2}$-furan & 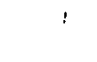 & 168 & 0.7 \\
\hline 19.59 & $\mathrm{C}_{2}$-furan & & 1,249 . & 5.2 \\
\hline 20.98 & methyl thiazole & & 2,688 & 20.0 \\
\hline 21.49 & methyl thiazole & & 464 & 3.5 \\
\hline 25.35 & n-decane & & 1,518 & 6.3 \\
\hline 26.01 & $\mathrm{C}_{3}$-furan & & 787 & 3.2 \\
\hline 26.84 & $\mathrm{C}_{2}$-thiazole & & 677 & 5.0 \\
\hline 28.87 & $\mathrm{C}_{2}$-thiazole & & 2,355 & 17.5 \\
\hline 29.17 & $\mathrm{C}_{2}$-thiazole & & 746 & 5.6 \\
\hline 29.34 & $\mathrm{C}_{2}$-thiazole & & 742 & 5.5 \\
\hline 30.00 & $\mathrm{C}_{3}$-thiazole & & 1,128 & 8.4 \\
\hline 30.90 & $\mathrm{C}_{3}$-thiazole & & 1,213 & 9.0 \\
\hline 31.61 & $\mathrm{C}_{3}$-thiazole & & 3,598 & 26.8 \\
\hline 32.41 & $\mathrm{C}_{3}$-thiazole & & 2,012 & 15.0 \\
\hline 32.96 & n-hendecane & & 4,222 & 17.4 \\
\hline 40.39 & n-dodecane & & 8,260 & 34.0 \\
\hline 42.02 & $\mathrm{C}_{2}$-cyclohexane & & 4,557 & 20.4 \\
\hline 43.07 & $\mathrm{C}_{2}$-cyclohexane & & 6,564 & 29.4 \\
\hline 45.22 & trimethyl cyclohexane & & 6,504 & 28.7 \\
\hline 45.64 & $\mathrm{C}_{2}$-cyclohexane & & 8,600 & 38.5 \\
\hline 46.68 & $\mathrm{C}_{14 \text {-alkane }}$ & & 10,790 & 47.2 \\
\hline 47.45 & n-tridecane & & 8,480 & 34.9 \\
\hline 52.71 & $C_{15-a 1 k a n e}$ & & 7,464 & 31.2 \\
\hline 54.12 & n-tetradecane & & 11,170 & 46.0 \\
\hline 58.23 & $\mathrm{C}_{16^{-a 1 k a n e}}$ & & 12,200 & 51.0 \\
\hline 60.41 & n-pentadecane & & 12,630 & 52.0 \\
\hline 66.38 & $\mathrm{n}$-hexadecane & & 13,510 & 55.6 \\
\hline 69.35 & $\mathrm{C}_{18 \text {-alkane }}$ & & 13,940 & 58.3 \\
\hline 72.03 & n-heptadecane. & & 14,780 & 60.8 \\
\hline 72.59 & pristane & & 19,080 & 78.5 \\
\hline 73.34 & unidentified & & 3,182 & - \\
\hline 73.66 & unidentified & & 3,104 & - \\
\hline 74.24 & unidentified & & 2,849 & - \\
\hline 77.37 & n-octadecane & & 8,588 & 35.9 \\
\hline 78.07 & phytane & & 8,648 & 36.1 \\
\hline 82.46 & n-nonadecane & & 7,594 & 31.7 \\
\hline 87.34 & n-eicosane & & 4,235 & 17.7 \\
\hline 91.97 & n-heneicosane & & 2,642 & 11.0 \\
\hline 96.43 & n-docosane & & 1,802 & 7.5 \\
\hline 100.68 & n-tricosane & & 1,353 & 5.7 \\
\hline 103.57 & unidentified & & 1,967 & - \\
\hline 104.79 & n-tetracosane & & 890 & 3.7 \\
\hline 108.73 & n-pentacosane & & 1,091 & 4.6 \\
\hline 112.50 & n-hexacosane & & 646 & 2.7 \\
\hline 116.15 & n-heptacosane & & 685 & 2.9 \\
\hline 119.68 & n-octacosane & & 541 & 2.3 \\
\hline 123.06 & n-nonacosane & & 580 & 2.4 \\
\hline
\end{tabular}


Table 5.2 (Contd.)

\begin{tabular}{llrc}
\hline $\begin{array}{l}\text { Retention } \\
\text { Time,.Min }\end{array}$ & Tentative Identification & Area Counts & $\begin{array}{c}\text { Concentration } \\
\mu \text { a/L }\end{array}$ \\
\hline 126.36 & n-triacontane & 377 & 1.6 \\
129.54 & n-hentriacontane & 307 & 1.3 \\
132.64 & n-dotriacontane & 99 & 0.4 \\
136.09 & n-tritriacontane & 114 & 0.5 \\
140.12 & n-tetratriacontane & 50 & 0.2 \\
\hline
\end{tabular}


Table 5.3 Compounds in Base Fractions of the Liquid Extract ( $1 \mu \mathrm{L}$ injection).

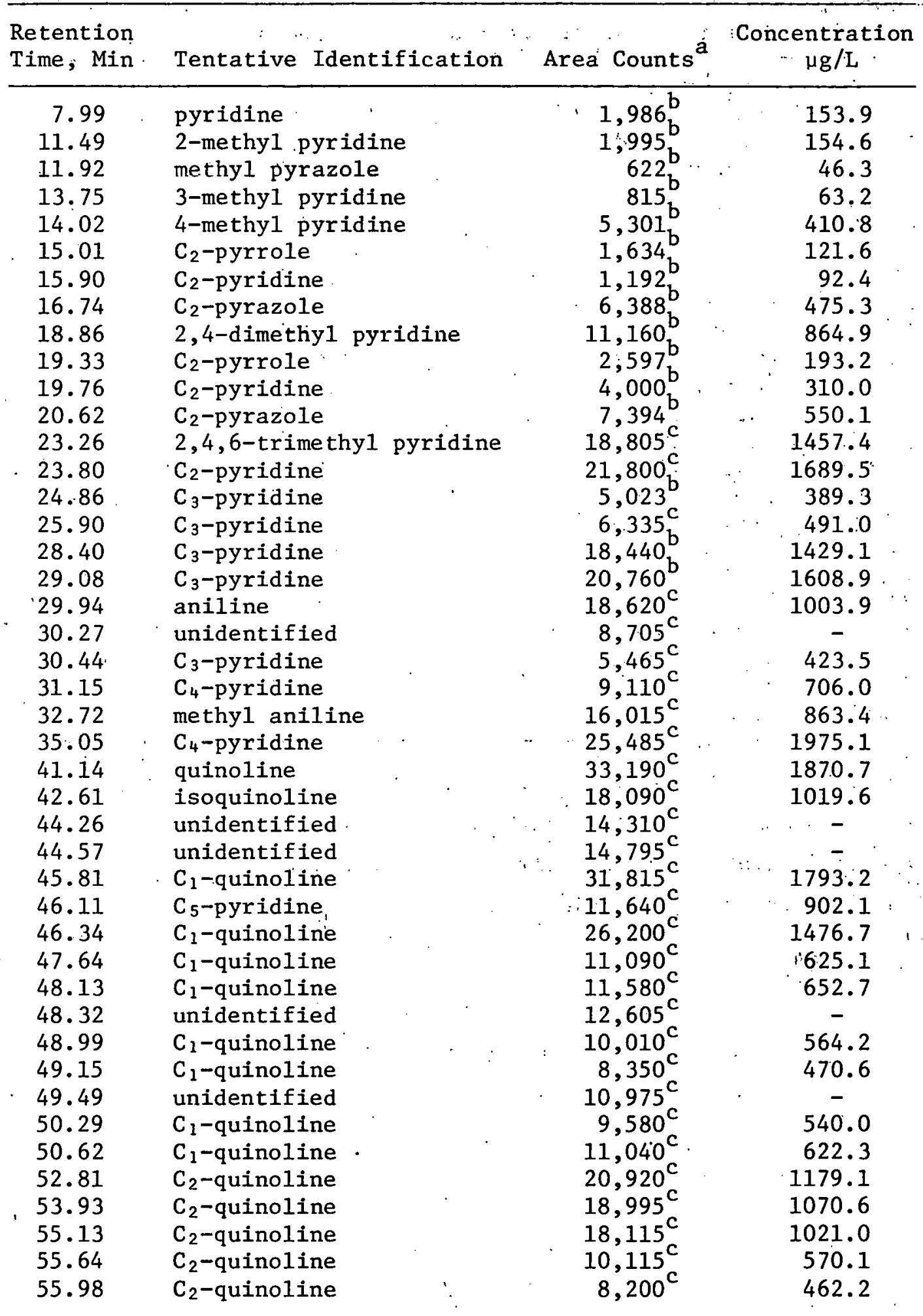


Table 5.3 (Contd.)

\begin{tabular}{llrc}
\hline $\begin{array}{l}\text { Retention } \\
\text { Time, Min }\end{array}$ & Tentative Identification & Area Counts & $\begin{array}{c}\text { Concentration } \\
\mu g / \mathrm{L}\end{array}$ \\
\hline 62.94 & unidentified & $10,188 \mathrm{~d}$ & - \\
63.65 & unidentified & $5,630 \mathrm{~d}$ & - \\
64.04 & unidentified & $8,869 \mathrm{~d}$ & - \\
64.69 & unidentified & $14,710^{\mathrm{d}}$ & - \\
65.92 & unidentified & $8,964 \mathrm{~d}$ & - \\
66.79 & unidentified & $5,639 \mathrm{~d}$ & - \\
67.39 & unidentified & $10,803 \mathrm{~d}$ & - \\
68.78 & unidentified & $16,617 \mathrm{~d}$ & - \\
69.47 & unidentified & $14,847 \mathrm{~d}$ & - \\
70.09 & unidentified & $11,881 \mathrm{~d}$ & - \\
70.48 & unidentified & $7,640 \mathrm{~d}$ & - \\
70.82 & unidentified & $6,059 \mathrm{~d}$ & - \\
71.27 & unidentified & $4,678 \mathrm{~d}$ & - \\
71.85 & unidentified & $7,256 \mathrm{~d}$ & - \\
72.05 & unidentified & $6,302 \mathrm{~d}$ & - \\
72.36 & unidentified & $16,199 \mathrm{~d}$ & - \\
73.82 & unidentified. & $4,311 \mathrm{~d}$ & - \\
74.27 & unidentified & $6,099 \mathrm{~d}$ & - \\
75.52 & unidentified & $8,119 \mathrm{~d}$ & - \\
75.83 & unidentified & $19,171 \mathrm{~d}$ & - \\
76.54 & unidentified & $2,668 \mathrm{~d}$ & - \\
78.43 & unidentified & $3,802 \mathrm{~d}$ & - \\
79.01 & unidentified & $6,397 \mathrm{~d}$ & - \\
79.55 & unidentified & $3,363 \mathrm{~d}$ & - \\
\hline
\end{tabular}

$a_{\text {For }} 1: 10$ diluted sample:

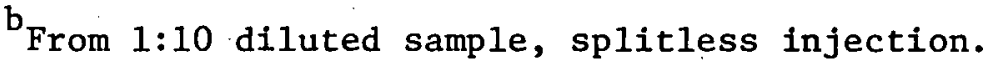

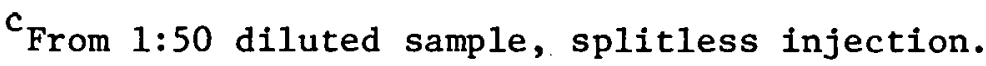

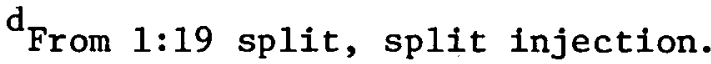


Table 5.4 Compounds in the Base Fraction of the Particulates Extract ( $1 \mu \mathrm{L}$, splitless)

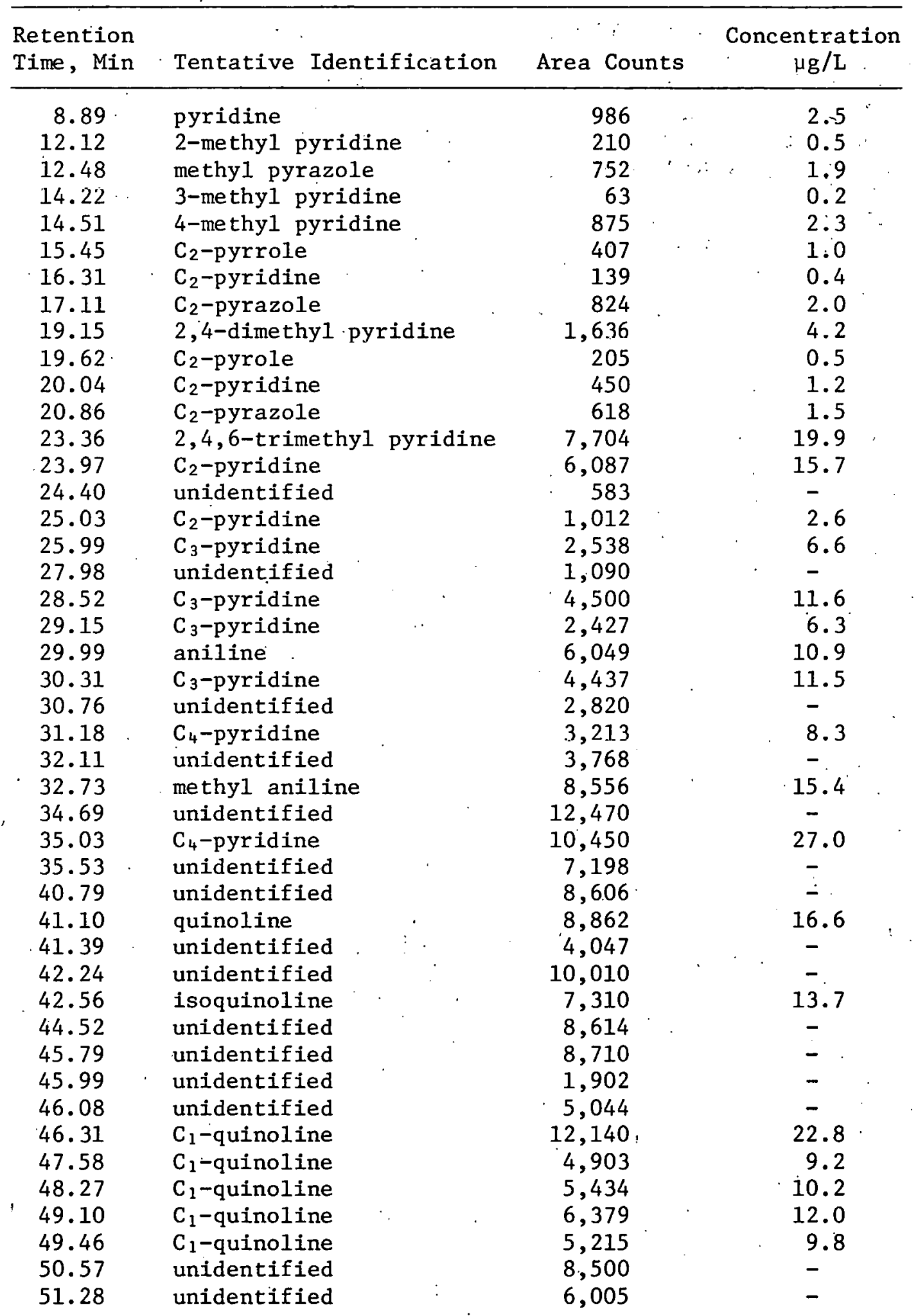


Table 5.4 (Contd.)

\begin{tabular}{clcc}
\hline $\begin{array}{l}\text { Retention } \\
\text { Time, Min }\end{array}$ & Tentative Identification & Area Counts & $\begin{array}{c}\text { Concentration } \\
\mu \mathrm{g} / \mathrm{L}\end{array}$ \\
\hline 52.78 & C 2 -quinoline & 8,778 & 16.5 \\
53.62 & unidentified & 3,986 & - \\
53.88 & C 2 -quinoline & 8,932 & 16.8 \\
54.41 & unidentified & 4,936 & - \\
55.13 & C2-quinoline & 17,010 & 32.0 \\
55.62 & C -quinoline & 7,690 & 14.4 \\
55.93 & unidentified & 6,065 & - \\
\hline
\end{tabular}


Table 5.5 Compounds in the Acid Fraction of the Liquid Extract (1 $\mu \mathrm{L}$, splitless, 1:10 dilution)

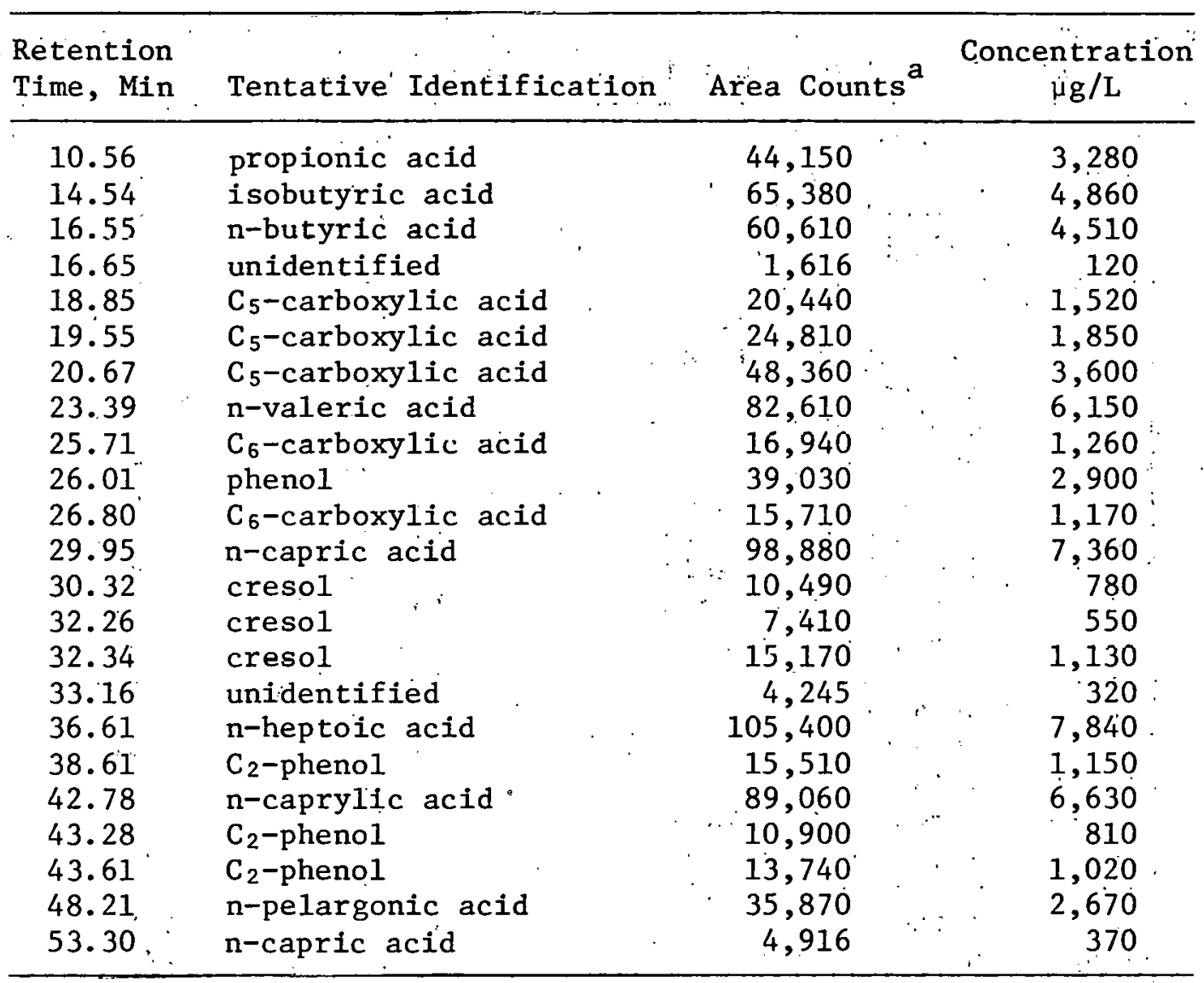

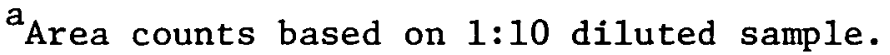


Table 5.6 Compounds in the Acid Fraction of the Particulates Extract ( $3 \mu \mathrm{L}$, splitless)

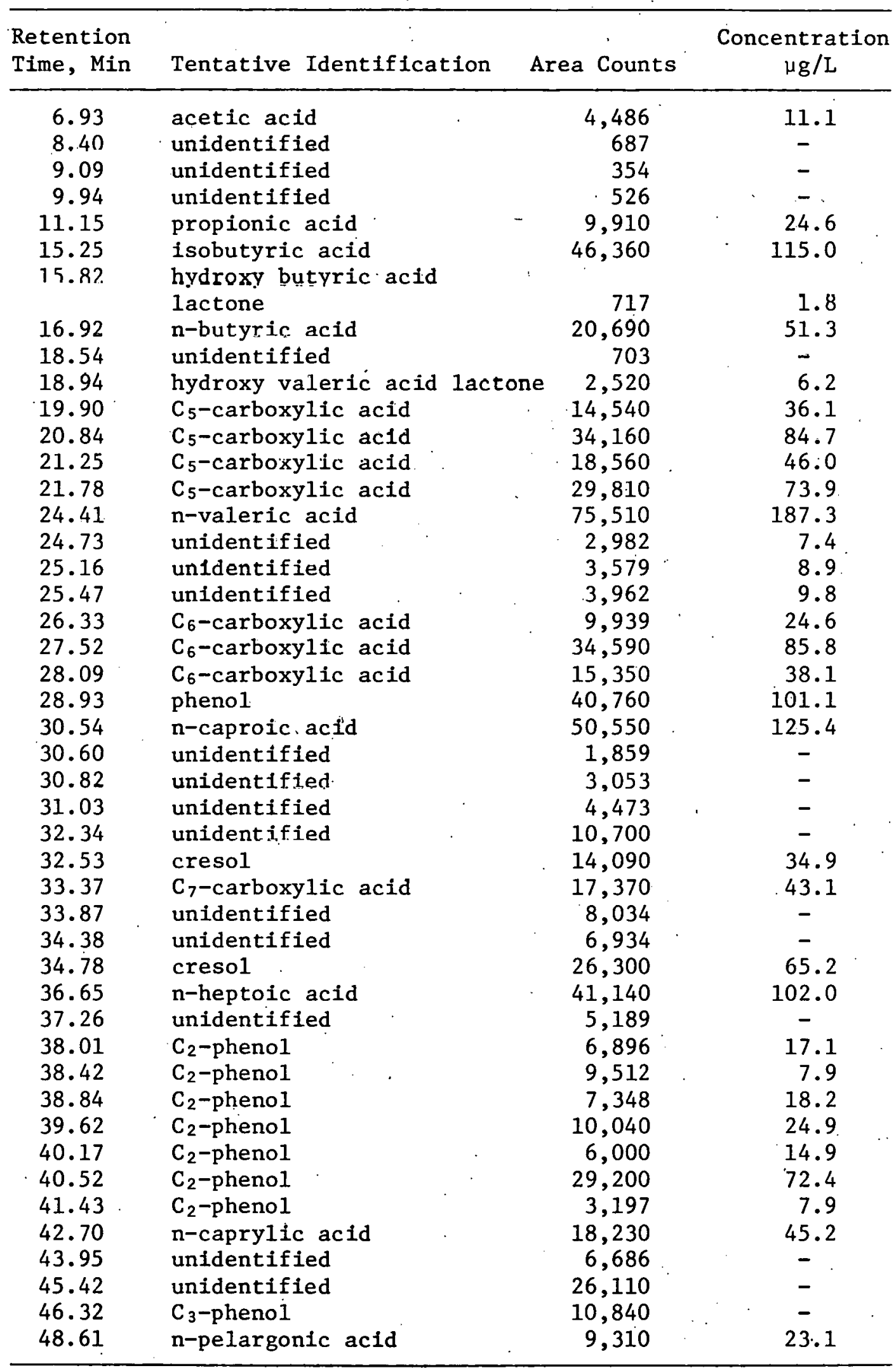




\section{REFERENCES}

American Society for Testing and Materials, Index of Mass Spectral, Data, Philadephia (1969).

Fox J.P., et al., Chemical Characterization and Analytical Considerations for an In-Situ Oil-Shale Process Water, Laramie Energy. Technology Center Report LETC/RI-78/7 (1978).

Heller, S.R. and G.W.A. Milne, EPA/NIH Mass Spectral Data Base, U.S. Govt. Printing office, Washington D.C. (1978).

Office of Technology Assessment, An Assessment of Oil Shale Technologies, U.S. Govt. Printing office, Washington, D.C. (1980).

Pellizzari, E.D., et al., Identification of Organic Components in Aqueous Effluents from Energy-Related Processes, ASTM Spec. 686, Philadelphia, pp. 256-274 (1979).

Raphaelian, L.A., and W. Harrison, Stability of Extractable Organic Constituents in Stored Samples of Gasification Condensates Inferred from Comparisons of GC/MS Total Ion Chromatograms, Argonne National Laboratory Report ANL/EMR-3 (Feb. 1979).

Stenhagen E., et al., Registry of Mass Spectral Data, John Wiley and Sons, Inc., New York (1974). 
Distribution for ANL/PAG-5

Internal

$\begin{array}{ll}\text { R. P. Carter } & \text { K. S. Macal } \\ \text { S-Y. Chiu } & \text { W. E. Massey } \\ \text { E. J. Croke } & \text { E. G. Pewitt } \\ \text { J. D. Ditmars } & \text { L. A. Raphaelian (10) } \\ \text { R. D. Flotard } & \text { J. J. Roberts } \\ \text { L. J. Habegger } & \text { D. M. Rote } \\ \text { W. Harrison (10) } & \text { W. K. Sinclair } \\ \text { A. B. Krisciunas } & \text { V. C. Stamoudis }\end{array}$

J. R. Stetter

T. G. Surles

M. F. Torpy (2)

S. L. Vargo (44)

K. E. Wilzbach (2)

ANL Contract Copy

ANL Libraries

TIS Files (6)

ANL Patent Dept.

Externa 1

DOE-TIC, for distribution per UC-91 (176)

Manager, Chicago Operations and Regional Office, DOE

President, Argonne Universities Association

Energy and Environmental Systems Division Review Committee:

E. E. Angino, University of Kansas

E. N. Castle, Resources for the Future, Inc.

R. L. Clodius, National Association of State Universities and Land Grant Colleges

B. A. Egan, Environmental Research and Technology, Inc.

W. W. Hogan, Harvard University

W. N. Poundstone, Consolidation Coal Company

L. H. Roddis, Jr., Charleston, S.C.

J. J. Stuke1, University of Illinois

J. J. Wortman, North Carolina State University

L. Anastasia, Institute of Gas Technology, Chicago

D. Ballantine, U.S. Department of Energy, Washington, D.C.

T. Baugh, U.S. EPA, Cincinnati

H. M. Brennan, Standard Oil Co. (Indiana), Chicago

P. Bui, Occidental Research Corp., Irvine, CA

F. Campbe11, Equity Oil Co., Denver

M. Carrington, U.S. Department of Energy, Washington, D.C.

F. Castaldi, Engineering-Science, Austin, TX

W. Chappell, University of Colorado/Denver

C. C. Daughton, University of California, Berkeley, Richmond, CA

J. Ellington, EPA, Athens, GA

B. Ewing, University of Illinois, Urbana

P. Ferraro, Colorado Dept. of Health, Denver

D. Ford, Engineering-Science, Austin, TX

P. Fox, Lawrence Berkeley Laboratory

R. Franklin, U.S. Department of Energy, Washington, D.C.

J. Fruchter, Battelle-Pacific Northwest Laboratory, Richland, WA

J. H. Gibbons, Office of Technology Assessment, U.S. Congress (2)

M. Gottlieb, U.S. Department of Energy, Washington, D.C.

E. T. Green, Kentucky Dept. for Natural Resource and Environmental Protection, Frankfort, $\mathrm{KY}$

C. Grua, U.S. Department of Energy, Washington, D.C. (10)

R. N. Heistand, Paraho Development Corp., Rifle, CO

R. E. Hicks, Water Purification Associates, Cambridge, MA 
L. P. Jackson, Laramie Energy Technologý Center, WY

B. M. Jones, Lawrence Berkeley Laboratory

D. E. Kash, U.S. Geological Survey, Reston, VA

T. A. Kauppila, Cleveland-Cliffs, Rifle, CO

R. Kirby, U.S. EPA, Washington, D.C.

S. H. Korper, Mathtech, Inc., Arlington, VA

J. A. Krebs, Multi Mineral Corp., Grand Junction, Co

R. Lewis, Monsanto Research, Dayton, $\mathrm{OH}$

W. Liberick, Jr., EPA, Cincinnati

J. Lotwala, Laramie Energy Technology Center, WY

R. G. Luthy, Carnegie-Melion University, Pittsburgh (3)

T. Mancini, WYO DEQ/WQD, Cheyenne

M. J. Massey, Environmental Res.\& Tech., Pittsburgh

H. Meiners, Union Oil Co. of California, Los Angeles

B. Mercer, Pacific Northwest Laboratory, Richland, WA

G. A. Miller, VSGS-Area 0il Shale office, Grand Junction, Co

L. Mims, Illinois Inst. of Natural Resources, Chicago

D. Natusch, Colorado State University, Fort Collins

A. R. Peters, C/O Chevron Research Co., Richmond, CA

T. Phillips, Laramie Energy Technology Center, WY

R. Poulson, Laramie Energy Technology Center, WY

J. E. Quigley and E. Megyesy, Mobil R\&D Corp., Paulsboro, NJ

G. D. Rawlings, Monsanto Research Corp., Dayton, OH

D. Sheesley, Laramie Energy Technology Center, WY

W. Smith, U.S. EPA, Washington, D.C.

V. Snoeyink, University of Illinois, Urbana

T. Spedding, Laramie Energy Technology Center

G. Stout, University of Illinois, Urbana

C. K. Sudweeks, Utah Dept. of Health, Salt Lake City

B. Telliard, U.S. EPA, Washington, D.C.

T. Thoem, U.S. EPA Region VIII, Denver

J. T. Turk, U.S. Geological Survey, Lakewood, CO

E. Turner, Occidental Oil Shale, Inc., Grand Junction, Co

D. Venardos, AMOCO Research Center, Naperville, IL

P. Wagner, Los Alamos Scientific Laboratory

E. C. Walker, Burns \& Roe, Paramus, NJ

J. Wallace, Denver Research Institute

H. Walter, U.S. Department of Energy, Washington, D.C.

J. Ward, Exxon U.S.A., Houston

F. Witmer, U.S. Department of Energy, Washington, D.C.

M. L. Yates, U.S. Geological Survey, Denver 